\title{
The Application of Emergency Concept Within the MUI Fatwa on Measles-Rubella Vaccine Immunization
}

\author{
Ahmad Sanusi ${ }^{1}$, Ahmad Harisul Miftah ${ }^{2}$, Ria Agustiana ${ }^{3}$
}

\begin{abstract}
Abstrack: The Application of Emergency Concept Within the MUI Fatwa on MeaslesRubella Vaccine Immunization. The term emergency (dharurat) often appears in the fatwas of contemporary scholars such as health emergencies (dharurat al-shihhiyah), cultural civilization emergencies (dharurat al-tsaqafiyah), and so on. The term is generally intended as material for consideration in resolving urgent legal issues (muljiah). This paper tries to analyze the MUI Fatwa Number 33 of 2018 concerning the Measles-Rubella Vaccine. According to LPPOM MUI, this vaccine contains elements that are considered haram in Islam. Therefore, the use of the vaccine is not allowed in religion. However, after conducting a thorough study, MUI, through the MUI Fatwa Number 33 of 2018, stated that even though the Rubella Measles Vaccine contains haram elements, it is still allowed to be used. The reason for this ability is an emergency because until now there is no other halal vaccine that can be used to fight the disease, even though the use of the vaccine is considered important and urgent for the safety of the life of the wider community, including the next generation of Muslims in Indonesia.
\end{abstract}

Keywords: Emergency and Maslahat Concept, MUI Fatwa, Measles-Rubella Vaccine

\begin{abstract}
Abstrak: Penerapan Konsep Darurat dalam Fatwa MUI pada Tindakan Imunisasi Vaksin Rubella. Istilah darurat (dharurat), seringkali muncul dalam fatwa-fatwa para ulama kontemporer seperti darurat kesehatan (dharurat al-shihhiyah), darurat peradaban budaya (dharurat al-tsaqafiyah), dan sebagainya. Istilah itu pada umumnya ditujukan sebagai bahan pertimbangan dalam menyelesaikan masalah hukum yang bersifat mendesak (muljiah). Makalah ini mencoba menganalisis Fatwa MUI Nomor 33 Tahun 2018 tentang Vaksin Rubella Campak. Menurut LPPOM MUI, vaksin ini mengandung unsur yang dianggap haram dalam Islam. Karena itu, penggunaan vaksin tersebut jelas tidak diperbolehkan secara agama. Namun, setelah melakukan kajian menyeluruh, MUI, melalui Fatwa MUI Nomor 33 Tahun 2018, menyatakan bahwa meski Vaksin Campak Rubella mengandung unsur haram, namun tetap diperbolehkan untuk dipergunakan. Alasan kebolehan ini adalah keadaan darurat dikarenakan hingga saat ini belum ada vaksin lain yang halal yang dapat digunakan untuk melawan penyakit tersebut, padahal penggunaan vaksin tersebut dipandang penting dan mendesak untuk kepentingan keselamatan kehidupan masyarakat luas, termasuk generasi penerus umat Islam di Indonesia.
\end{abstract}

Kata Kunci: Konsep Darurat dan Maslahat, Fatwa MUI, Vaksin Rubella Campak

\footnotetext{
${ }^{1,2}$ Faculty of Sharia and Law, UIN Sultan Maulana Hasanuddin, Banten, Indonesia

${ }^{3}$ Postgraduate Program in Islamic Studies, Yarmouk University, Irbid, Jordan

E-mail: ${ }^{1}$ ahmad.sanusi@uinbanten.ac.id, ${ }^{2}$ ahmad.harisul.miftah@uinbanten.ac.id, ${ }^{3}$ riaagustinatohawi@yahoo.com
} 


\section{Introduction}

There is an assumption that the concept of dharurat in Islamic law specifically only applies to people who are in a state of necessity, like a person who is in the forest and he does not find other food besides pork. In this case, he may eat the pork because he is in a state of emergency regardless of the fact that any part of pork, whether its meat, bones, oil, or anything that comes from it, is forbidden to use (haram). With the emergence of several fatwas issued by the Indonesian Council of Ulama (MUI), however, this assumption seems irrelevant. Using the concept of dharurat as the basis of argument, the MUI Fatwa commission allows the use of the Rubella Micelle (MR) vaccine, despite it is identified as containing pork, and, therefore, is considered haram. MUI Fatwa Number 33 of 2018 was issued in an effort to support the Ministry of Health's program of the Republic of Indonesia concerning the eradication of infectious diseases through the respiratory tract caused by the MR.4 virus. The eradication program is carried out by administering vaccines to children aged 9 months to less than 15 years using the MeaslesRubella Vaccine (MR) from the Serum of India Institute, which based on BPPOM research, contains pork.

The issue being debated among many people is whether something that has been explicitly declared haram (unlawful) can change to halal (lawful) based on emergency reasons? To answer this question, a very comprehensive is needed. This article will examine in depth the concept of dharurat (state of emergency) and relate it to the MUI fatwa Number 33 of 2018 regarding the use of the Rubella Measles (MR) vaccine in the immunization program. This is because to issue a fatwa, individuals or groups must go through the correct and valid methodology (istinbath al-ahkam), involving the principles of fiqhiyah and ushuliyah outlined by previous Muslim scholars. ${ }^{1}$

${ }^{1}$ wahyu Fadhilatul Hikmah And Zainal Azwar, 'Hukum Vaksin Measles Rubella (Analisis Fatwa Mui Nomor 33 Tahun 2018)', Jurnal Al-Ahkam, 11.1 (2020), 19-33; See Also Husni Mubarrak, 'Penalaran Istishlâhîi Dalam Kajian Fikih Kontemporer: Studi Kasus Fatwa Hukum Imunisasi Di Aceh', Ahkam: Jurnal Ilmu Syariah, 17.1 (2017) <Https://Doi.Org/10.15408/ Ajis.V17i1.6225>; Ahmad Hasan Ridwan And Asep Rahmat, 'Dimensi Kondisionalitas Dan Fleksibilitas Al-Quran Bagi Implementasi Fatwa Dsn-Mui Tentang Produk Bank Syariah’, Jurnal 


\section{Method}

This research is qualitative. By using the content analysis method, the work explains the concept of dharurat in the form of ushul al-fiqh from various Islamic schools of thought. This method is used to analyze the MUI fatwa on the application of the dharurat concept in Islamic law perspective regarding the use of the Measles-Rubella Vaccine for the immunization in the context of preventive act and emergency condition. In this work, some classical and contemporary literature, including the results of interviews with a number of informants, will be studied and used as a reference in analyzing the object of research, namely the MUI fatwa regarding the permissibility of using the measles vaccine. In the data analysis process, the researcher will combine deductive and inductive methods through a descriptive approach, then perform an analysis based on the content analysis method to formulate conclusions.

\section{The History of MUI and Fatwa Commission}

The background of the establishment of the Indonesian Ulema Council was the holding of the National Ulama Conference on October 4, 1970, at the Islamic Dakwah Center Jakarta. The idea for the establishment of MUI appeared in the paper of one of the speakers in the forum, Prof. Dr. K.H. Ibrahim Husen, Chancellor of the Quranic Islamic College (PTIQ). In his presentation, Ibrahim Hosen quoted the decision of Majma 'al-Buhuts al-Islamiyah (مجمع البحوث الاسلامية) in Cairo, Egypt in 1964 which stated the importance of jama'i ijtihad. For this reason, he proposed to form the Indonesian Ulama Council which would function as an institution that gives fatwas on various religious issues that arise or are proposed by the Indonesian Muslim community. However,

\footnotetext{
Asy-SyariAh Faculty Sharia And Law Uin Sunan Gunung Djati Bandun, 22.1 (2020); Muhammad Maulana Hamzah, 'Peran Dan Pengaruh Fatwa Mui Dalam Arus Transformasi Sosial Budaya Di Indonesia', Millah: Jurnal Studi Agama, 1.1 (2018), 127-54 <Https://Doi.Org/10.20885/ Millah.Vol17.Iss1.Art7>; Ahmad Mukri Aji And Diana Mutia Habibaty, 'Fatwa Majelis Ulama Indonesia Tentang Penyelenggaraan Ibadah Dalam Situasi Terjadi Wabah Covid-19 Sebagai Langkah Antisipatif Dan Proaktif Persebaran Virus Corona Di Indonesia', Salam: Jurnal Sosial Dan Budaya Syar-I, 7.8 (2020), 673-86 <Https://Doi.Org/10.15408/Sjsbs.V7i8.17059>; Jamal Makmur, 'Peran Fatwa Mui dalam Berbangsa dan Bernegara', Wahana Akademika: Jurnal Studi Islam Dan Sosial, 5.2 (2019), 41-52 <https://doi.org/10.21580/wa.v5i2.3226>.
} 
his idea was strongly rejected by Buya Hamka, a respected senior cleric at the time. His rejection was mainly related to the involvement of secular ulama in collective ijtihad. Instead, Buya Hamka recommended that the President of the Republic of Indonesia, at that time Soeharto, choose a mufti who would act as a provider of religious advice to both the government and all Muslim citizens in Indonesia. ${ }^{2}$

Four years later, in 1974, the Islamic Dakwah Center again held a national conference that was attended by scholars. The conference mandate stated that the participants agreed to encourage the importance of establishing the Indonesian Ulema Council and also recommended its formation in each province. This is in line with President Soeharto's statement which stated the importance of the existence of an ulama institution for a country to lead people to better practice religious teachings.

A year later, on May 24, 1975, President Soeharto, after receiving a delegation from the Indonesian Mosque Council (DMI), reaffirmed the importance of establishing the Indonesian Ulema Council. Finally, on 21-27 July 1975, a National Ulama Congress was held again, which was attended by a number of figures representing the central management of Islamic mass organizations, such as $\mathrm{KH}$ Moh. Dahlan, as a representative of Nahdlatul Ulama (NU), Ir. H. Basit Wahid as a representation of Muhammadiyah, H. Syafi'i Wirakusumah as a representation of the Islamic Syarikat, H. Nurhasan Ibnu Hajar as a representation of the Islamic Tarbiyah Association, Anas Tanjung as a representation of alWasliyah, from KH Saleh Suaidi as a representation of Mathlaul Anwar, KHS Qudratullah as a representation of the Islamic Education Renewal Business Movement, H. Sukarsono as a representative of the Islamic Da'wah College, KH Hasyim Adnan as a representative of the Indonesian Mosque Council, H. Zaenal Arifin Abbas as a representative of al-Ittihadiyah, as well as a number of other independent scholars including 4 scholars from the Spiritual Islamic Service of the Indonesian Army Force, Air Force, Navy Force, and the Indonesian Police, and 13

${ }^{2}$ Asrorun Ni'am Sholeh, Metodologi Penetapan Fatwa Majelis Ulama Indonesia (Jakarta: Emir, 2016), p. 90. 
recognized Muslim scholars who were invited individually. ${ }^{3}$ The most interesting thing here is that this conference was held after the formation of MUI at the regional level throughout Indonesia, and even became the initiator for the formation of MUI at the central level. ${ }^{4}$

At the end of the conference, it was declared the establishment of the organization of the Indonesian Ulama Council at the central level, which was signed by 53 participants consisting of 26 newly formed regional MUI chairs, 10 ulama from central level Islamic organizations, 4 ulama from regional MUI. This incident occurred on 17 Rajab 1395 $\mathrm{H}$, coinciding with July 26, 1975. With the official establishment of the MUI, since then Indonesia has also had a religious institution (Islam), which has the right and authority to provide answers to people's questions about problematic religious issues, similar to Jordan's Supreme Judge (Qadhi al-Qudhat), or Mufti. Dyar in Egypt, and a number of other Islamic countries such as Saudi Arabia, Iraq, and others.

As for the Fatwa Commission, this institution was formed simultaneously with MUI in 1975 and is one of the commissions that has an important role in that institution. The main duties of this Commission include examining, discussing, and formulating religious (Islamic) issues that arise in society, as well as providing legal views (fatwas) to serve as guidelines for the wider community. ${ }^{5}$

From its formation until now, the MUI Fatwa Commission has undergone five changes of chairman. 1. K.H. A. Syukri Ghazali (19751981), a Nahdlatul Ulama cleric figure who is quite authoritative and respected; 2. K.H. Ibrahim Hosen (1981-2000). He was born in Bengkulu in 1917, and one of the founders of the MUI as well as a scholar who holds the title, Professor. 3. K.H Ma'ruf Amin (2000-2007). was born in Tangerang, March 11, 1943, a scholar who has a background in Islamic boarding school education, but managed to achieve the highest academic degree as a Professor of UIN Maulana Malik Ibrahim Malang.

${ }^{3}$ Asrorun Ni'am Sholeh, p. 71.

${ }^{4}$ Bahrul Ulum, Ulama Dan Politik, Nalar Politik Kebangsaan :Majelis Ulama Indonesia (Yogyakarta: Pustaka Pelajar, 2015), p. 89.

${ }^{5}$ Article 5 Number (1) until (3) of MUI statute 
Currently serving as Vice President of the Republic of Indonesia for the period 2019-2024; 4. Dr. K.H. Anwar Ibrahim (2007-2010). He is an alumnus of Al Azhar University in Cairo, Egypt. Aside from being the Chairman of the MUI Fatwa Commission, he is also active in teaching at the Jakarta Institute of Sciences (IIQ) Al-Quran and as Chairman of the Nahdlatul Ulama Syuriah Council (2004-2009); 5. Prof. Dr. H. Hasanudin AF, MA (2010-2015). He was born in Majalengka, West Java in 1945. He obtained his Bachelor of Sharia degree at IAIN Jakarta in 1974, including his MA and Doctoral degrees from the same university in 1989 and 1994. He was reappointed as Chair of the MUI Fatwa Commission for the 2015-2020 period in the IX MUI Congress in 2015.

\section{The Concept of Dharurat in Fiqh}

Etymologically, the word al-dharurat (emergency) comes from Arabic which has been absorbed into Indonesian, and is taken from the word aldharar which means danger, compelling or difficult conditions. In defining dharurat, a number of Ushul scholars, both former (mutaqaddimin) and contemporary (mu'ashirah) have different views, though not far off, on what exactly is meant by the term.

The word dharurat in the dictionary of al-Mujam al-Wasit is defined as a need (hajah), or something that cannot be avoided (la madfa'a laha), or difficulty (masyaqqah). ${ }^{6}$ Al-Jurjani, in his work Al-Ta'rifat, explains that the word al-dharurat is formed from al-dharar (madharat), which is a disaster that cannot be avoided. Meanwhile, Al-Jasshash, when discussing severe hunger (makhmashah), said that an emergency is the fear of damage or destruction of soul or body parts if you do not eat. ${ }^{7}$ A similar definition was put forward by al-Badzawi who explained that the definition of emergency was related to severe hunger so that if a person did not eat he would lose his soul or limb. ${ }^{8}$

${ }^{6}$ Ibrahim Mustafa, Al-Mu jam al-Wasit, Juz 1 (t.tp: al-Maktabah al-Syamilah, t.t), p. 1115.

7 Wahbah Al-Zuhaily, Nazhariyyaat Al-Dharuurah al-Syariah; Muqaranah Ma' al-Qanun al Wadhi, Edition IV (Beirut: Muassasah Al-Risalah), p. 66.

${ }^{8}$ Wahbah Al- Zuhaily, p. 66. 
Al-Zarkasyi and al-Suyuthi defined the term dharurat as the arrival of a person at the limit where if he does not want to eat what is forbidden, then he will perish, or approach perishing. Like a person who is forced to eat something haram where if he doesn't do it he will die or lose some limbs.

The Qur'an has described this emergency in a number of verses, which specifically emphasize severe hunger (makhmasah) or being in a state of food emergency. As mentioned in the Qur'an, Surat An-Nahl verse 115 :

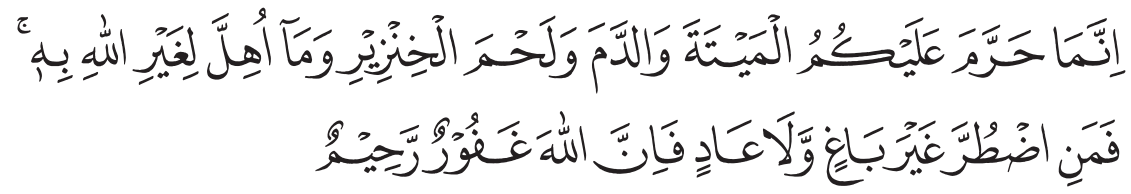

Indeed, Allah only forbids you (to eat) carrion, blood, pork, and what is slaughtered by mentioning a name other than Allah; but whoever is forced to eat it without persecuting or exceeding the limit, then Allah is Most Forgiving, Most Merciful (Surah An-Nahl: 115).

In the Surah al-Maidah Allah says:

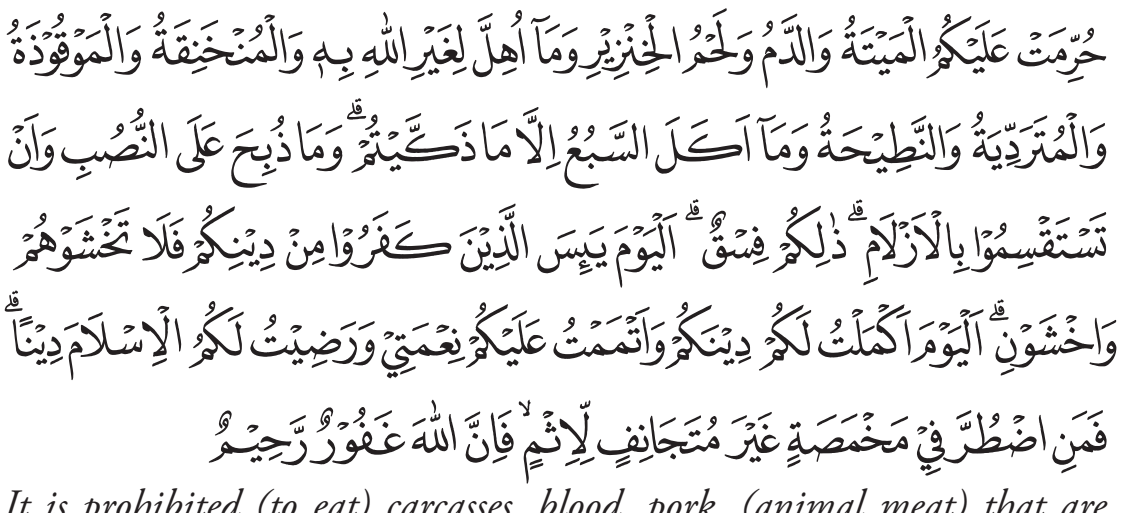

It is prohibited (to eat) carcasses, blood, pork, (animal meat) that are slaughtered in the name of other than Allah, those who are strangled, those who are beaten, those who fall, who is gored, and are killed by wild beasts, except those you have slaughtered, and (forbidden to you) slaughtered for idols, and (forbidden also) to draw fate with arrows.

${ }^{9}$ Wahbah Al- Zuhaily, p. 15. 
To draw fate with an arrow is wickedness. On this day the disbelievers have given up (overcoming) your religion, so do not be afraid of them and fear me. On this day I have perfected your religion for you, and I have provided for you My blessings, and I have accepted Islam as your religion. So whoever is forced out of hunger accidentally commits a sin, then, in fact, Allah is Most Forgiving, Most Merciful (Surah Al-Ma'idah: 3).

\section{The Criteria of Dharurat and Fiqh Regulation}

The scholars of fiqh divide human needs into 5 types, each of which has a different order (maratib) or level. Each of these types/levels of need will have different effects and logical consequences from a legal perspective.

The types of living necessities referred to above are classified as follows:

1. Al-dharurat is a certain condition in which if a person does not do certain actions such as - eating haram - then there is a strong belief or that he will die soon. In this condition, a person can do things that are prohibited by religion (mahdhurat).

2. Al-hajat is synonymous with the word "necessity", namely a condition of someone who is in dire need of something but is not overshadowed by death. Al-hajat can also be classified as a condition of emergency without certainty or in general it does not end in death. For example, the necessity to break the fast for someone who is fasting when he experiences extreme fatigue or extreme thirst and hunger.

3. Al-manfa'at is the urge or desire to enjoy certain items, such as eating nutritious food and so on. Al-manfa'at can be interpreted as natural human needs. In the study of fiqh, benefits are classified into needs that are tabsiniyyah and kamaliyyah. The tabsiniyah is a natural need, while kamaliyyah is a need whose fulfillment is for refreshing (taraffu), or life can be better enjoyed. Islam appreciates this type of need and recommends that it be preserved in all aspects of life as long as it does not exceed the limits determined or prohibited by law. 
4. Al-Zinah is the desire to get a certain luxury or enjoyment. For example, the desire to have an expensive vehicle, a luxurious house, and others. The difference between al-zinah and al-manfaah is that if al-zinah is not fulfilled, human survival will not be threatened and there will be no trouble at all because of its absence. The absence of al-zinah generally only affects one's dignity in an economic context. For instance, a billionaire who only owns cheap cars.

5. Al-Fudhul is the behavior of human life that has exceeded the limit alias excessive. In the terminology of fiqh, al-fudhul can be defined as an excessive act that can cause a person to be trapped in the abyss of syubhat or haram, such as eating on plates made of gold or silver, building a very spacious and luxurious house. Al-Fudhul is an act that must be avoided because there is no respect or legitimacy from Islamic law: ${ }^{10}$

Referring to the five types of needs above, al-dharurat and al-hajat receive relief and consideration from the Islamic law in the form of certain exceptions even though they are categorized as syubhat or haram. To apply the use of the concept of Darurat, several principles need to be understood as a guide in seeing a legal problem. The principles referred to among others are:

1. يَُالُ الضَّرَرُ (Severe difficulties/danger must be removed)

This principle implies that everything that can cause great harm or loss must be eliminated. For example, someone who allows an infectious disease to enter his body without trying to treat it. The actions of this person cannot be tolerated by Shara 'because it is against the principle that harm must be eliminated or large losses must be eliminated.

2. ألمَحْظُوْرَات تُبْيْحُ الضَّرُوْرَةُ (In an emergency, there is the ability to do things that are prohibited)

This principle is a branch rule of the principle that everything harmful must be eliminated (principle no. 1 above). This principle

${ }^{10}$ Muchlis Usman, Kaidah-Kaidah Ushuliyah Dan Fiqhiyyah: Pedoman Dasar Dalam Istinbath Hukum Islam (Jakarta: PT. Raja Grafindo Persada, 1999), pp. 132-33. 
emphasizes that in an emergency, it is permissible to do something that is prohibited provided that the level of emergency is not lower than what is actually prohibited and that no other alternative is found. For example, it is permissible to eat a carcass in a state of necessity because of hunger and there is no other food apart from that, cleaning the throat of a person who is choking with wine, destroying/seizing the property of a person who is reluctant to pay a debt without his permission, refusing to attack the opponent even though it can cause the attacker to die, cut down trees and destroy buildings of infidels for war purposes, dig up graves of bodies after being buried for emergency reasons, namely because they are buried before being bathed, or because they do not lead to the Qibla, or are buried in booty or shrouds from the spoils.

3. الحاجة تنزل منزلة الضرورة عامة أو خاصة (Urgent needs can occupy a position of emergency either in general or specifically).

The purpose of this principle is that it is permissible to do what is prohibited under an emergency (al-dharurat), both in general and specifically. For example, eating pork is absolutely haram according to the Qur'an and Hadith, but one may eat it in extreme hunger while no other food is available.

4. بَقَدَّرَها يُقَدَّرُ لِضَّرُوْرَةِ أُبِيْحُ مَا (something that is allowed due to an emergency is limited to the size of the emergency)

The purpose of this rule is to emphasize that something permissible for reasons of al-dharurah (emergency) or al-hajah (necessity) must not exceed the limit of the needs to reject or avoid that situation).

5. بالضرر لايزال الضرر (A state of danger cannot be eliminated by other dangers)

The purpose of this rule is that a person who is facing an emergency, must not repel or avoid himself from this situation by causing harm/ loss to others.

6. إذاتعارض مفسدتان روعي أعظمها ضرر بارتكاب أخفهما (If there are two conflicting emergencies, the thing with the highest level of emergency must be prioritized) 
This rule is a further elaboration of the above Islamic rules on how to prioritize doing at the most emergency level. In other words, each person needs to choose the level of difficulty that is the most severe and should be left while the situation with the level of emergency/ difficulty is less. ${ }^{11}$

\section{The Application of Dharurat Concept in Fiqh}

Among the conditions that can be classified as an emergency are thirst and medical treatment. The state of thirst and treatment is the same as the state of hunger. Because neglect of thirst fulfillment or medication has the potential to be a cause of death. Therefore the Jumhur scholars allow a person to drink khamar when thirsty, choking, or forced to just avoid an emergency and there is no other alternative. ${ }^{12}$ As for treatment using prohibited items, Islamic jurists have a different opinion. A number of salaf and khalaf scholars say that it is not permissible to use unlawful items such as drinking wine or other haram items. They argue with the following hadith:

1. Hadith narrated by Ahmad, Abu Dawud, and Tirmidhi, from Tariq ibn Suwaid that he once asked the Prophet Muhammad about khamar. Then the Apostle forbade or disliked his actions. Said Tariq ibn Suwaid, "I only made it for medicine?" Rasulullah SAW replied: "This is not a medicine but a disease."

2. Also narrated by Abu Dawud and Tirmizi from Ibn al-Darda: "Verily Allah SWT has created disease and medicine, therefore seek treatment, but not with haram things."

On the other hand, the Hanafiah figh experts argue that it is permissible to seek treatment with haram if one believes it is the cure and there is no other medicine that can replace it. If only within the estimated limits, then not allowed.

${ }^{11}$ A. Djazuli, Kaidah-Kaidah Fikih: Kaidah-Kaidah Hukum Islam Dalam Menyelesaikan Masalah-Masalah Yang Praktis (Jakarta: Kencana Prenada Media Grup, 2006), pp. 72-77.

${ }^{12}$ Wahbah Al- Zuhaily, p. 81. 
Another example is treatment with a carcass. According to Abdul Aziz Muhammad Azzam's study on this topic, Imam al-Qurthubi said:

"Treatment with carcasses of course requires use in its original form or half burned. If it has been replaced by burning, then according to Ibn Habib it can be used for treatment and can be brought for prayer, because burning is purifying, and because there is a change in its characteristics. It was also narrated by Imam Malik that martak (a type of medicine from a carcass) should not be drunk before being washed clean. Likewise, original carcasses or pork, according to Sahnun, should not be used as medicine, because they can be replaced with other drugs taken from ingredients that are allowed to be used."13

\section{Analyzing the Application of the Emergency Concept of the MUI Fatwa on Measles-Rubella Vaccine}

\section{Measles-Rubella (MR) Vaccine}

In the medical world, Measles and Rubella are known as two diseases that are similar but have different symptoms. Measles can be recognized by the appearance of a high fever, red patches on the skin (rash) accompanied by a cough and/or runny nose, and/or conjunctivitis (red eyes). On the other hand, Rubella is often referred to as German measles. ${ }^{14}$ This disease is similar to measles but not as severe as measles which often attacks and can cause death. ${ }^{15}$ The characteristics of red spots on the skin experienced by people with measles are not always experienced by people with Rubella, even these symptoms are rarely seen. Symptoms of red spots on the skin only appear in 15-20\% of Rubella sufferers. Measles and Rubella are acute and mild diseases that attack children and young adults. ${ }^{16}$ However, in general, the characteristics of Measles and Rubella sufferers are difficult to detect because they are similar to one another. So it is difficult to tell whether a child is infected with measles

${ }^{13}$ Abdul Aziz Muhammad Azzam, Fiqh Muamalat (Jakarta: amzah, 2010), p. 520.

${ }^{14}$ Aep Syaiful Hamidi, Imunisasi Alami Untuk Anak (Yogyakarta: saufa, 2014), p. 9.

${ }^{15}$ Tim Penyusun, Petunjuk Teknis Kampanye Dan Introduksi Imunisasi Measles Rubella (MR) (Jakarta: Direktorat Jenderal Pencegahan dan Pengendalian Penyakit Kementerian Kesehatan RI, 2017), p. 2.

${ }^{16}$ Tim Penyusun, Pedoman Surveilans Campak - Rubela, (Jakarta: Kemenkes RI, 2020, p.3. 
or Rubella. The only way to confirm someone has the Rubella virus is through laboratory results. ${ }^{17} \cdot{ }^{18}$

Mild symptoms of the Rubella vaccine include rash (spots), low fever, red eyes, muscle aches, and nasal congestion. ${ }^{19}$ This virus can attack all age groups, not only children but also adults with low immunity. When someone gets measles, $90 \%$ of people who interact with the sufferer can get it if they do not have immunity to the disease. This immunity can be obtained after a person has been exposed to the disease or if he has been immunized. ${ }^{20}$

Measles, also known as Morbilli, appears to be caused by a virus. Rubella is also caused by the rubivirus togavirus, which belongs to the RNA virus group. Rubella is transmitted through the respiratory tract when coughing or sneezing. The virus can multiply in the nasopharynx and regional lymph nodes, and viremia 4-7 days after the virus enters the body. The period of transmission is estimated to occur 7 days before to 7 days after the rash. The incubation period for Rubella ranges from 14-21 days. Symptoms and signs of Rubella are characterized by lowgrade fever $\left(37.2^{\circ} \mathrm{C}\right)$ and a red rash or maculopapular rash with enlarged lymph nodes behind the ears, back of the neck, and suboccipital. ${ }^{21}$

For Rubella, what is important about this disease is its impact on pregnant women or what is often referred to as a teratogenic effect (effect on the fetus). This effect occurs when a mother who is pregnant and passes the first trimester is exposed to the Rubella virus. The fetus can miscarry, or if the baby is born will have a congenital defect called congenital Rubella syndrome (CRS). Clinically, CRS is a congenital disorder ranging from eye disorders, such as cataracts and glaucoma, hearing loss, congenital heart defects, can even cause microcephaly or head shrinkage, bone disorders, liver, and spleen. The proportion of disability based on gestational age increases in the first trimester and decreases with

${ }^{17}$ Faisal Yatim, Macam-Macam Penyakit Menular Dan Cara Pencegahannya, 2nd ed. (Jakarta: Pustaka Obor Populer, 2017), pp. 129-30.

${ }^{18}$ Tim Penyusun, Pedoman Surveilans..... p.3.

${ }_{19}$ Tim Penyusun, Petunjuk Teknis.....p.2

${ }^{20}$ Tim Penyusun, Petunjuk Teknis

${ }^{21}$ Tim Penyusun, Petunjuk Teknis 
increasing gestational age. ${ }^{22}$ This disease can also cause death. This happens when there are complications in it, such as malnutrition or malnutrition. In 2000 , more than 526,000 children per year died worldwide from complications of measles. The solution given was immunization, until finally in 2014 the data showed a decrease in the death rate from Measles from 526,000 to 115,000 per year, with an estimated 314 children per day or 13 deaths per hour. ${ }^{23}$

CRS cases vary in the community, between $0.1-2 / 1000$ live births in the endemic period and $0.8-4 / 1000$ live births in the Rubella endemic period. Nationally, in cases of Rubella, 23\% occurred in children over 15 years, and $77 \%$ in the age group under 15 years. According to Syamsu, in 2012 there were 160 extraordinary cases (KLB) of measles in Indonesia with a total of $\pm 2,300$ cases. Of these outbreaks, 73 or $45 \%$ can be confirmed by the laboratory as pure measles and $45 \%$ of these cases are Rubella. In 2014 there were 185 suspected measles outbreaks with a total of almost 2000 cases, of which there were Rubella outbreaks. Then of the 5,700 who were identified clinically, which means someone was diagnosed by a doctor as having measles not based on laboratory results, $16 \%$ of them were Rubella. ${ }^{24}$

More complete data is provided by the Indonesian Ministry of Health's Data and Information Center which carries out surveillance activities every year. Surveillance activities carried out annually report more than 11,000 suspected measles cases, which are divided into 12 $39 \%$ confirmed measles and 16 - 43\% Rubella.

In 2010 - 2015 there were an estimated 23,164 cases of measles and 30,463 cases of Rubella. Measles cases in the last three years have also shown an increase in several provinces but some have experienced a decline. The increase occurred in 18 provinces $(52.9 \%)$ such as North Sumatra, Riau, Jambi, South Sumatra, Bengkulu, Riau Islands, East Java, Banten, Bali, NTB, NTT, West Kalimantan, Central Kalimantan, East Kalimantan, South Sulawesi, Southeast Sulawesi, Maluku, and West

\footnotetext{
${ }^{22}$ Tim Penyusun, Pedoman Surveilans p.17.

${ }^{23}$ Tim Penyusun, Petunjuk Teknis.....p. 1.

${ }^{24}$ Tim Penyusun, Pedoman Surveilans p.20-25.
} 
Papua. ${ }^{25}$ Meanwhile, for Rubella cases, surveillance data for the last five years showed $70 \%$ of cases of Rubella occurred in the age group $<15$ years. In addition, based on a study on the estimated burden of CRS in Indonesia in 2013, it was estimated that there were 2767 cases of CRS, $82 / 100,000$ occurred at the maternal age of 15-19 years and decreased to $47 / 100,000$ at the maternal age of $40-44$ years. $^{26}$

One of the efforts that Indonesia has made to prevent measles and rubella outbreaks is by maximizing the routine immunization program. Immunization is a medical intervention that is expected to be able to eliminate the incidence of measles and rubella. The government, in this case, the Ministry of Health, wishes to carry out an MR immunization campaign. "Because, if it is too late, while other countries have already done it, then Indonesian citizens who are going to travel abroad will receive different treatment because they are worried that they will carry this virus. 27 The campaigns were carried out in 2017 and 2018 outside Java aim to increase people's immunity to Measles and Rubella quickly, simultaneously, and massively to break the chain of virus transmission in the community. As we all know the number of cases has been successfully reduced. Measles and rubella can heal on their own if there are no complications. But if there are complications, then this disease can lead to death. For example, if a patient suffered from measles also suffers from malnutrition, then he or she can die. In order for this disease to be prevented early, immunization is needed. Rubella measles vaccine immunization is the best prevention for measles and Rubella as one vaccine prevents two diseases." 28

Rubella vaccine is used in the immunization program to prevent the spread of measles and Rubella virus (Measles Rubella). This vaccine is an imported vaccine for partnerships that work in synergy with developing countries. This vaccine is manufactured by Serum Institute of India Pvt.

${ }^{25}$ Kemenkes RI, 'Infodatin Pusat Data Dan Informasi Kementerian Kesehatan RI, Situasi Campak Dan Rubella Di Indonesia', (Jakarta: Kemenkes RI, 2018), p. 3.

${ }^{26}$ Tim Penyusun, Petunjuk Teknis.....p. 2.

${ }^{27}$ Ministry of Health Republic of Indonesia. Kemenkes lanjutkan kampanye imunisasi MR sampai Desember. Available: https://www.kemkes.go.id/article/view/18110200002/kemenkeslanjutkan-kampanye-imunisasi-mr-sampai-desember.html.

${ }^{28}$ Ministry of Health Republic of Indonesia. Kemenkes lanjutkan kampanye imunisasi $M R$. 
Ltd. (SII) which is under the auspices of the Cyrus Poonawalla Group. As is known, SII is the largest vaccine producer in the world with a production of more than 1.3 billion doses. The vaccines produced include polio, diphtheria, tetanus, pertussis, Hib, BCG, hepatitis B, measles, mumps, including the Rubella vaccine. Vaccines produced by SII have gone through a strict accreditation and supervision process from WHO. So far, the vaccines produced by SII have supported national immunization programs in 170 countries and have saved millions of lives worldwide. ${ }^{29}$

Rubella vaccine is available in the monovalent form or combination with other viral vaccines such as measles (Rubella measles) or with measles and parotitis (Rubella measles mumps). To stimulate the human immune system, vaccines are made from live attenuated viruses or viruses or inactivated components. The process of weakening the virus is carried out through a laboratory process. Attenuated vaccines cause disease to appear, but symptoms are relatively mild compared to those that are acquired naturally. ${ }^{30}$

Rubella measles vaccine is a new vaccine but with old standards considering that measles is an old disease. Rubella vaccine as a new variant of measles is then combined with other antigens so that it becomes a recombinant (combined) antigen. So the Rubella vaccine is not given alone/single antigen but in combination with measles. Even other countries have a combination of four: MMRV, Measles, Mumps, Rubella, and Varicella. Most of the world uses three: Measles, Mumps, and Rubella. There are also countries using MR (two) with the consideration that goiter is not very common, its prevalence is low. ${ }^{31}$

Indonesia's commitment to eradicating the Rubella measles virus will also be implemented in 2020, then revised in 2023, with the following achievement strategies:

29 'About Serum Institute Of India Pvt. Ltd.' read <https://www.seruminstitute.com/ about_us.php>.

${ }^{30}$ J.B. Suharjo B. Cahyono, at.all, Vaksinasi Cara Ampuh Cegah Penyakit Infeksi (Yogyakarta: Kanisius, 2010), p. 32.

${ }^{31}$ Ministry of Health Republic of Indonesia. Kemenkes lanjutkan kampanye imunisasi $M R$ 
a. Strengthening routine immunization to achieve measles immunization coverage $\geq 95 \%$ at all levels;

b. Implementing the measles crash program for children aged 9 - 59 months in 185 districts/cities in August - September 2016;

c. The implementation of the MR vaccine campaign in children aged 9 months to 15 years is gradually conducted in 2 stages:

- Phase 1 (August - September 2017) in Java Island;

- Phase 2 (August - September 2018 in all regions of Sumatra, Kalimantan, Sulawesi, Bali, Nusa Tenggara, Maluku and Papua;

d. Introducing the MR vaccine into the routine immunization program in October 2017 and 2018;

e. Individual case-based Rubella Measles or Case-Based Measles Surveillance (CBMS);

f. CRS Surveillance Sentinel in 13 Hospitals;

g. Investigating Measles Extraordinary Events. ${ }^{32}$

\section{The MUI Fatwa on Measles-Rubella Vaccine Immunization}

Two years before the issuance of MUI Fatwa Number 33 of 2018, ${ }^{33}$ MUI issued Fatwa Number 4 of 2016 stating that immunization is permissible (mubah) as an effort to create immunity and prevent certain diseases. The fatwa also regulates vaccine status. Vaccines for immunization are required to use vaccines that are halal and holy. The use of immunization vaccines made from haram or unclean is haram except

${ }^{32}$ Tim Penyusun, Petunjuk Teknis....p. 4.

33 See Fatwa MUI Number 33 of 2018 on The Use of MR Vaccine (Measles Rubella) produced by SII (Serum Institute of India). This fatwa contains four legal provisions, namely: (1) the use of vaccines that contain pork and its derivatives is haram; (2) MR vaccine products from the Serum Institute of India (SII) are also haram because in the production process they use ingredients derived from pigs; (3) currently, the use of MR Vaccine products from the Serum Institute of India (SII) is permitted (change) because: (a) there is a condition of compulsion (dharurat al-syariyyah); (b) another MR vaccine that is halal and holy is still unavailable. and (c) there is information from a competent and trusted expert about the dangers caused by not being vaccinated and the absence of a halal vaccine; (4) the use of the MR vaccine as referred to in number 3 does not apply if a halal and holy vaccine is found. See Fatwa MUI Number33 of 2018 on The Use of MR Vaccine (Measles Rubella) Produced by SII (Serum Institute of India) for Vaccine. 
in an emergency as there is no halal vaccine, supported by information from competent medical personnel regarding the unavailability of halal vaccines. $^{34}$

In the next two years, MUI issued a letter of recommendation to the Directorate General of Disease Prevention and Control of the Ministry of Health of the Republic of Indonesia regarding campaign support and the introduction of Rubella (MR) measles immunization in 2017 and 2018. The letter contained several recommendations such as:

a. The government is obliged to guarantee the maintenance of public health through promotive, preventive, curative, and rehabilitative approaches;

b. The government is obliged to ensure the availability of halal MeaslesRubella (MR) vaccine for the benefit of immunization for the community;

c. The MUI Fatwa Commission supports the implementation of the immunization program as an effort to maintain health through the use of halal vaccines;

d. The government is obliged to immediately implement mandatory halal certification for all vaccines, including Rubella Measles (MR) vaccine, and ask producers to immediately apply for halal certification of vaccine products;

e. Vaccine producers are required to strive for the production of MeaslesRubella (MR) vaccine that is halal and carry out halal certification in accordance with the provisions of laws and regulations;

f. The government together with religious and community leaders need to socialize the implementation of immunization in general, including the implementation plan for Rubella Measles (MR) immunization;

${ }^{34}$ At first sight, the MUI Fatwa Number 4 of 2016 and the Number 33 of 2018 are similar to one another. Both have the same legal background. It is as if the 2018 fatwa is a continuation of the 2016 fatwa, which embodies the previous MUI fatwa that immunization must be related to the necessity to use halal vaccine products. The fatwa was then refined with a 2018 fatwa which stated that the use of the MR virus was prohibited due to the use of haram materials. 
g. Parents and the community need to participate in maintaining health, including through providing support for the implementation of the immunization program with Measles-Rubella (MR) vaccine immunization. ${ }^{35}$

The government, through the Indonesian Ministry of Health, responded to the recommendation by submitting a letter numbered: SR.02.06 / Menkes / 449/ 2018 concerning the request of the MUI Fatwa on the Implementation of Measles-Rubella Immunization in Indonesia the essence of the letter is to explain that the Rubella Measles immunization campaign is an implementation of the government's obligation together with the community to protect children and society in Indonesia from harm. measles and rubella.

In the next stage, the MUI Fatwa Commission convened to assess whether the MR immunization had met the halal product standards or not. Several stages had been passed, including the LPPOM MUI study which led to a conclusion about the MR vaccine. At the MUI Fatwa Commission session on August 15, 2018, the results of the research were read out and it was concluded that the MR Vaccine used several ingredients derived from elements that are forbidden in Islam, namely:

a. The gelatin material comes from pork skin and trypsin from the pork pancreas;

b. Materials that have a high chance of affecting contact with pigs in the production process, namely lactalbumin hydrolysate;

c. The material that comes from the human body is human diploid cells.

In the next stage, the MUI Fatwa Commission convenes to assess whether MR immunization has met the halal product standard or not. Several stages have been passed, including the LPPOM MUI study which led to conclusions on the results of his research on the MR vaccine. At the MUI Fatwa Commission hearing on August 15, 2018, the results of the research were read and concluded that there was the use of several

${ }^{35}$ Recommendation Letter of MUI Number: U-13/MUI/KF/VII/2017 to Dirjen P2P Kemenkes RI 
ingredients derived from elements that are forbidden in Islam, namely pork, such as:

a. Gelatin ingredients derived from pork skin and trypsin from the pork pancreas;

b. The materials that have a great chance of influencing into contact with pigs in the production process, namely lactalbumin hydrolysate;

c. The materials come from the human body, namely human diploid cells.

Furthermore, to get a complete picture, MUI invites experts and specialists who know best about the MR Vaccine. Therefore, at the Fatwa Commission session on 17 August 2018, many competent parties were presented such as the General Director of Disease Prevention and Control of the Ministry of Health of the Republic of Indonesia, Chairperson of the National Commission for Immunization (Post Immunization Association), IDAI Management (Indonesian Pediatrician Association), ITAGI Management ( Indonesian Technical Advisory Group for Immunization) and Director of PT Biofarma. From the session, some official views regarding the MR virus are formulated, as follows:

a. Measles is a highly contagious disease caused by a virus and transmitted through coughing and sneezing. Symptoms of measles are high fever, red spots on the skin (rash) accompanied by cough and/or runny nose and/or conjunctivitis and can cause complications such as pneumonia, diarrhea, meningitis, and even death. When someone gets measles, $90 \%$ of people who have close interaction with the sufferer can get it if they are not immune to measles. Immunity develops if they have been immunized or previously infected with the measles virus;

b. Rubella is an acute and mild disease that frequently infects susceptible children and young adults. This disease is easily transmitted, but what is of concern in public health is the teratogenic effect when Rubella attacks pregnant women, especially in the early stages of pregnancy. Rubella infection in pregnant women can cause miscarriage or permanent disability in babies born, known as Congenital Rubella Syndrome (CRS); 
c. Complications of measles that can cause death are pneumonia and inflammation of the brain (encephalitis). Nearly 1 in 20 people with measles will experience complications of pneumonia and 1 in 1000 sufferers will experience complications of inflammation of the brain. In addition, other complications are ear infections that cause deafness ( 1 in 10 patients), diarrhea ( 1 in 10 patients) which causes the patient to be hospitalized;

d. The number of measles and rubella cases and deaths in the last 5 years in Indonesia are; 2014: 12,943 suspected cases with 15 deaths (2,241 measles positive, 906 Rubella positive); 2015: 13,890 suspected cases with 1 death (1,194 positives for measles, 1,474 positive for Rubella); 2016: The number of suspected cases was 12,730 with 5 deaths $(2,949$ positive for measles, 1,341 positive for rubella); 2017: number of suspected cases 15,104 with 1 death (2,197 positives for measles, 1,284 positive for Rubella); and 2018 (until July): 2,389 cases (383 measles positive, 732 Rubella positive), bringing the total reported measles-rubella cases in the last 5 years to 57,056 cases $(8,964$ measles positive, 5,737 cases positive for Rubella). About $89 \%$ of measles cases are suffered by children under 15 years of age. Meanwhile, for Rubella, about $77 \%$ of sufferers are children under 15 years of age;

e. Based on the results of a study on the situation of measles and rubella in Indonesia conducted by the Ministry of Health together with experts from WHO and academics from medical faculties and public health faculties in Indonesia conducted in October 2014, taking into account the immunization coverage situation and incidence of measles and rubella, a campaign is recommended MR immunization is carried out with a target age of 9 months to $<15$ years. If the targeted campaigns are not carried out as recommended, there will be an increase in the number of measles cases and the accumulation of Rubella;

f. The implementation of the MR immunization campaign is intended to increase the community's immunity against the transmission of measles and rubella which can cause disability and death. Also to 
reduce the transmission of the Measles and Rubella virus, reduce the morbidity of Measles and Rubella and reduce the incidence of CRS;

g. The implementation of MR immunization in Indonesia uses the MR vaccine produced by the Serum Institute of India with the consideration that the MR vaccine has received a WHO recommendation and the amount is sufficient, while there are two other MR vaccine products, namely Japanese products which are only sufficient for national needs and have not been exported, as well as Chinese products. which have not received a recommendation from WHO regarding their safety standards. : ${ }^{36}$

After a series of sessions of the MUI Fatwa Commission which were held in stages, the Fatwa Commission finally formulated a fatwa which was determined as an MUI Fatwa decision. The legal provisions of the MUI fatwa stated that the use of vaccines that utilize elements prohibited in Islam, such as pork and their derivatives, is haram. Therefore, the MR vaccine produced by the Serum Institute of India (SII) is included in the haram category because in the production process it uses ingredients derived from pigs. ${ }^{37}$

However, the MUI did not simply decide that the MR vaccine should not be used in the vaccination program. Other aspects are also taken into consideration namely the existence of coercive conditions (dharurat al-syar'iyyah), the absence of a halal vaccine, and the presence of competence and trusted expert testimony about the dangers that arise if immunization with the MR vaccine is not carried out. These three things, according to MUI, have serious implications for public health. For these reasons, after referring to the syara's arguments and using the ushuliyyah approach, MUI concluded that although basically, the MR vaccine is haram, it still can be used for state emergency reasons (dlarurah).

\footnotetext{
36 See MUI Fatwa Number 33 of 2018.

37 See MUI Fatwa Number33 of 2018.
} 
Taking seriously the entire above description of the stages and legal steps taken by the MUI before formulating the fatwa on the use of the MR vaccine, it can be said that normatively and methodologically the application of the emergency theory in the MUI fatwa is correct and appropriate. Normatively, the use of the theory of emergency conditions in reconstructing a legal product is indeed permissible and has a reference to the shari'a argument, especially the verse of the Qur'an QS. Al-Baqarah [2]:173), S. Al-An'am: 119), as well as fiqhiyah principles, among others :

1. يُرَالُ الضَّرَرُ (Severe difficulties/danger must be removed)

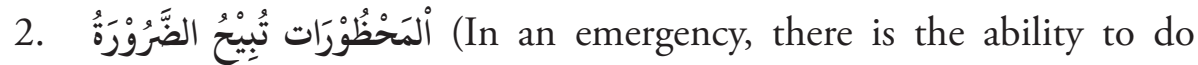
things that are prohibited)

3. الحاجة تنزل منزلة الضرورة عامة أو خاصة (Urgent needs can occupy a position of emergency either in general or specifically).

4. بَقَدَّرَها يُقَدَّرُ لِضََْرُوْرَةِ أُبِيْحُ مَا (something that is allowed due to an emergency is limited to the size of the emergency)

5. بالضرر لايزال الضرر (A state of danger cannot be eliminated by other dangers).

6. إذاتعارض مفسدتان روعي أعظمها ضرر بارتكاب أخفهما (If there are two conflicting emergencies, the thing highest level of emergency must be prioritized)

Furthermore, methodologically, MUI has also taken the right steps and procedures. This is indicated by the steps that have been taken by MUI when formulating an emergency, namely by using 3 criteria, namely: a situation that is feared does exist and occurs, there is no other alternative vaccine that can be used, and information from experts that a major disaster will occur. befall the community if vaccination is not carried out.

Based on the normative and methodological review above, it can be said that the use of the emergency principle in the MUI fatwa regarding the use of the Measles-Rubella vaccine can be justified and considered appropriate because it is carried out after seeing and considering the special situations and conditions related to the outbreak. 


\section{Conclusion}

Based on the description above, it can be concluded that:

1. Normatively, the application of emergency theory to construct law in the perspective of Islamic fiqh is justified because it has references and supports both in the Qur'an, al-Hadith, and Qaidah Fiqhiyah.

2. Methodologically, the application of the emergency theory by the MUI Fatwa regarding the use of the Measles-Rubella vaccine is correct and appropriate. This is because the emergency conditions (dharurat al-syar'iyyah) that are feared do indeed exist and occur; based on information from competent and trusted experts, if immunization is not carried out it will cause many toddlers or the elderly to be affected by the disease and are at risk of death or disability for life. Meanwhile, another alternative, in the form of a halal and holy MR vaccine, is not yet available or has not been obtained.

3. In order that the emergency does not continue to occur, it is recommended that:

a. The government must make every effort to seek other vaccines that are similar but not contain haram elements.

b. Medical producers, while producing vaccines or drugs, are required to make religious considerations, especially in terms of holy and halal medicines to the needs of Muslim-populated countries.

\section{Bibliography}

A. Djazuli, Kaidah-Kaidah Fikih: Kaidah-Kaidah Hukum Islam Dalam Menyelesaikan Masalah-Masalah Yang Praktis (Jakarta: Kencana Prenada Media Grup, 2006)

Abdul Aziz Muhammad Azzam, Figh Muamalat (Jakarta: amzah, 2010) 'About Serum Institute Of India Pvt. Ltd.' <https://www.seruminstitute. com/about_us.php>.

Aep Syaiful Hamidi, Imunisasi Alami Untuk Anak (Yogyakarta: saufa, 2014)

Ahmad Hasan Ridwan and Asep Rahmat, 'Dimensi Kondisionalitas Dan Fleksibilitas Al-Quran Bagi Implementasi Fatwa DSN-MUI Tentang 
Produk Bank Syariah', Jurnal Asy-Syari'ah Faculty Sharia and Law UIN Sunan Gunung Djati Bandun, 22.1 (2020)

Aji, Ahmad Mukri, and Diana Mutia Habibaty, 'Fatwa Majelis Ulama Indonesia Tentang Penyelenggaraan Ibadah Dalam Situasi Terjadi Wabah Covid-19 Sebagai Langkah Antisipatif dan Proaktif Persebaran Virus Corona Di Indonesia', SALAM: Jurnal Sosial dan Budaya Syar-i, 7.8 (2020), 673-86 <https://doi.org/10.15408/sjsbs.v7i8.17059>

Asrorun Ni'am Sholeh, Metodologi Penetapan Fatwa Majelis Ulama Indonesia (Jakarta: Emir, 2016)

Bahrul Ulum, Ulama Dan Politik, Nalar Politik Kebangsaan Majelis Ulama Indonesia (Yogyakarta: Pustaka Pelajar, 2015)

Faisal Yatim, Macam-Macam Penyakit Menular Dan Cara Pencegahannya, 2nd edn (Jakarta: Pustaka Obor Populer, 2017)

Hamzah, Muhammad Maulana, 'Peran Dan Pengaruh Fatwa Mui Dalam Arus Transformasi Sosial Budaya Di Indonesia', Millah: Jurnal Studi Agama, 1.1 (2018), 127-54 <https://doi.org/10.20885/millah.vol17. iss 1.art7>

Hikmah, Wahyu Fadhilatul, and Zainal Azwar, 'Hukum Vaksin Measles Rubella (Analisis Fatwa MUI Nomor 33 Tahun 2018)', Jurnal ALAHKAM, 11.1 (2020), 19-33

Ibrahim Mustafa, Al-Mu'jam al-Wasit, Juz 1 (t.tp: al-Maktabah alSyamilah, t.t)

J.B. Suharjo B. Cahyono, at.all, Vaksinasi Cara Ampuh Cegah Penyakit Infeksi (Yogyakarta: Kanisius, 2010)

Kemenkes RI, 'Infodatin Pusat Data Dan Informasi Kementerian Kesehatan RI, SituasiCampak Dan Rubella Di Indonesia', (Jakarta: Kemenkes RI, 2018)

Makmur, Jamal, 'Peran Fatwa Mui Dalam Berbangsa Dan Bernegara', Wahana Akademika: Jurnal Studi Islam Dan Sosial, 5.2 (2019), 41-52 <https://doi.org/10.21580/wa.v5i2.3226>

Mubarrak, Husni, 'Penalaran Istishlâhî dalam Kajian Fikih Kontemporer: Studi Kasus Fatwa Hukum Imunisasi di Aceh', AHKAM: Jurnal Ilmu Syariah, 17.1 (2017) <https://doi.org/10.15408/ajis.v17i1.6225> 
Muchlis Usman, Kaidah-Kaidah Ushuliyah Dan Fiqhiyyah: Pedoman Dasar Dalam Istinbath Hukum Islam (Jakarta: PT. Raja Grafindo Persada, 1999)

Prof. Dr. H. Ahmad Sutarmadi, MA., a member of the MUI Fatwa Commission, emergency condition in the Surah al-Baqarah verse 173,2019

Syamsu Alam, Pedoman Surveilans Campak - Rubela, (Jakarta: Kemenkes RI, 2020).

Tim Penyusun, Petunjuk Teknis Kampanye Dan Introduksi Imunisasi Measles Rubella (MR (Jakarta: Direktorat Jenderal Pencegahan dan Pengendalian Penyakit Kementerian Kesehatan RI, 2017)

Wahbah Al-Zuhaily, Nazhariyyaat Al-Dharuurah al-Syariah; Muqaranah Ma' al-Qanun al Wadhi, Edition IV (Beirut: Muassasah Al-Risalah) 